\title{
The HND mouse, a nonobese model of type 2 diabetes mellitus with impaired insulin secretion
}

\author{
Fumihiko Horio $^{1,2}$, Shin Teradaira ${ }^{2}$, Tsunehiko Imamura ${ }^{2}$, Rea Victoria P Anunciado ${ }^{2}$, Misato Kobayashi ${ }^{2}$, \\ Takao Namikawa ${ }^{2}$ and Ichiro Niki ${ }^{3}$ \\ ${ }^{1}$ Department of Food and Nutritional Sciences, College of Bioscience and Biotechnology, Chubu University, Matsumoto-cho 1200, Kasugai 487-8501, \\ Japan, ${ }^{2}$ Department of Applied Molecular Bioscience, Graduate School of Bioagricultural Sciences, Nagoya University, Nagoya, Japan and ${ }^{3}$ Department of \\ Pharmacology, Oita University Faculty of Medicine, Oita, Japan
}

(Correspondence should be addressed to F Horio; Email: horiof@isc.chubu.ac.jp)

\begin{abstract}
Objectives: This study aimed to develop a novel type 2 diabetes model designated the HND (Horio-Niki diabetic) mouse, by transferring diabetogenic genes from wild castaneus mice (Mus musculus castaneus) captured in the Philippines into laboratory mice (C57BL/6J:B6).

Methods: Offspring from the cross between a wild male and a B6 female were backcrossed to the sire. One male backcross which exhibited fasting hyperglycemia was crossed with a B6 female to comprise the fundamental stock (F0). Thereafter, full-sib mating was performed, and mice with impaired glucose tolerance were selected and bred from the F2 generation. Characterization of the phenotype of HND mice and insulin release from their islets was evaluated with F12 generation males.

Results: The male HND mice were lean, and spontaneously exhibited impaired glucose tolerance at a high incidence rate at 6 weeks of age. Their serum insulin levels in response to intraperitoneal glucose were markedly attenuated. However, glucose-induced insulin release from isolated HND islets was not affected. Notably, inhibition of glucose-induced insulin release by epinephrine was more pronounced in HND islets than in $\mathrm{B} 6$ islets. Moreover, in vivo treatment of HND mice with the $\alpha 2$-adrenergic receptor agonist clonidine resulted in marked hypoinsulinemic hyperglycemia.

Conclusions: We suggest the HND mouse may be a distinctive and useful model for type 2 diabetes with impaired neural control of insulin secretion.
\end{abstract}

European Journal of Endocrinology 153 971-979

\section{Introduction}

Type 2 diabetes mellitus, a common, multiple generelated disease, is defined as chronic hyperglycemia resulting from genetic and environmental factors and eventual multiorgan disfunction (1). Diabetic animal models have greatly contributed to the analysis of its etiology and pathogenesis as well as development of antidiabetic treatment. Historically, the experimental and pharmacologic models for diabetes were developed in early studies. Subsequently, animal models which develop diabetes spontaneously have been established by the breeding study (2). Recently, more and more mouse models have been developed by transgenesis, that is, overexpression or depletion of diabetes-related genes.

More and more attention has been paid to the investigation of diabetes-related genes. Some monogenic forms of diabetes mellitus, such as maturity-onset diabetes of the young, and other mutations in the candidate genes included in glucose metabolism and $\beta$-cell development, have been identified by the human genetic approach (3). However, the gene defects are found rather uncommonly in type 2 diabetes subjects, and most of the genes responsible for the disease remain to be clarified (4). Spontaneously diabetic models are invaluable to identify these unknown diabetogenic genes. Spontaneous monogenic models for type 2 diabetes have helped to clarify the pathogenesis of type 2 diabetes, and the primary genetic lesions of these mutant models, such as Lep ${ }^{\mathrm{ob}}$, Lepr ${ }^{\mathrm{db}}$, Lepr ${ }^{\mathrm{fa}}$ and $C p e^{\text {fat }}$, have been identified by positional cloning and candidate gene analysis (5-8). However, these identified diabetogenic genes can account for only a small part of human type 2 diabetes. Therefore, development of spontaneous diabetic models with polygenic backgrounds is needed to search for novel diabetogenic genes responsible for common diabetes.

Type 2 diabetes results from impaired insulin secretion from pancreatic $\beta$-cells and/or insulin resistance of peripheral tissues. These two factors contribute to the formation of the disease to variable extents. In the majority of Japanese type 2 diabetic subjects, impaired insulin secretion from pancreatic $\beta$-cells precedes the development of overt diabetes. Several spontaneous 
polygenic models of type 2 diabetes, such as the OLETF rat, the KK-Ay mouse, the NSY mouse and the TSOD mouse, develop overt obesity and hyperinsulinemia prior to the onset of diabetes $(9-12)$. Notably, the GK rat exhibits distinct dysfunction of pancreatic $\beta$-cells without obesity (13). However, at present, available polygenic models of nonobese type 2 diabetes are very few.

Novel genetic traits with unique properties have been studied in wild mice populations, some of which have never been found in laboratory mice (14), and wild mice populations with hyperglycemia possibly carry diabetogenic genes. Some of these diabetogenic genes may function as 'thrifty genes' that allow better utilization of a limited food supply but increase the predisposition to diabetes when the food supply is abundant $(15,16)$. There is a strong expectation that approaches using polygenic diabetic models derived from wild mice will find novel diabetogenic genes or thrifty genes. Moreover, wild mice have an advantage in mapping mutated genes over laboratory strains owing to the higher level of polymorphisms in the microsatellite markers in wild mice.

In this study, we developed a novel polygenic type 2 diabetes model designated the HND (Horio-Niki diabetic) mouse, by transferring diabetogenic genes from wild castaneus mice (Mus musculus castaneus) captured in the Philippines into laboratory mice (C57BL/6J:B6). The HND mice exhibited mild hyperglycemia with impaired insulin secretion in response to epinephrine.

\section{Materials and methods}

\section{Animal management}

All mice were maintained in a room at a controlled temperature of $23 \pm 3{ }^{\circ} \mathrm{C}$ and humidity of $55 \pm 5 \%$ in a 12-h light/dark cycle. Mice had access ad libitum to regular laboratory chow (Labo MR Stock, Nihon Nosan Kogyo K.K., Yokohama, Japan) and drinking water. All procedures were in accordance with the Experimental Animal Guide of Nagoya University.

\section{Breeding methods}

We chose castaneus and B6 mice to develop a novel type 2 diabetes model for the following reasons:

1. The unique genetic characteristics of wild castaneus mouse may include the 'thrifty gene' leading to diabetes upon exposure to abundant food supply.

2. The laboratory strain B6 possesses the genes for type 2 diabetes induced by high-fat diet $(17,18)$.

3. The high rate of genetic polymorphism between these two subspecies will be valuable in future mapping studies (19).

4. The reproductive advantage with the fertile offspring would be observed in this intersubspecific mating (19).
We selected and mated diabetic mice identified by the intraperitoneal glucose tolerance test (IPGTT) (see below). This selective breeding method has been applied to the development of a few polygenic type 2 diabetes models $(9,11,13,20)$. The wild castaneus mice used in this study were captured in the Philippines in June 1994. The breeding methods and the pedigree are shown in Fig. 1. The F1 female offspring derived from the cross between the wild castaneus males and the B6 females were tested for fasting blood glucose concentrations. F1 females had higher fasting blood glucose levels than B6 females. F1 female offspring were backcrossed to the sire to produce the backcross progeny. A 10-week-old male backcross with the highest fasting blood glucose concentration $(190 \mathrm{mg} / \mathrm{dl})$ was selected and backcrossed to the B6 females. Thus derived offspring were defined as the fundamental stock (FO). Mice with relatively higher fasting blood glucose levels were selected for breeding in the FO and F1 generations. The IPGTT (see below) at 8 weeks of age was used to select diabetic mice from the F2 and the succeeding generations. The genetic background of HND mice of the F2 generation originated from B6 mice $(62.5 \%)$ and the wild-caught castaneus mouse $(37.5 \%)$. At present, selective breeding has been progressed to F16 generations. In this study, we characterized the F12 male mice. The female mice were used mostly for breeding purposes and were not tested for glucose tolerance.

\section{Body-mass index, measurement of blood glucose and serum insulin, and IPGTT}

The body weight and anal-nasal length of these mice were measured at 6-40 weeks of age. The body-mass index (BMI) was calculated as body weight $(\mathrm{g})$ divided by the square of the anal-nasal length $(\mathrm{cm})$. Blood samples were obtained from the tail vein of nonfasting

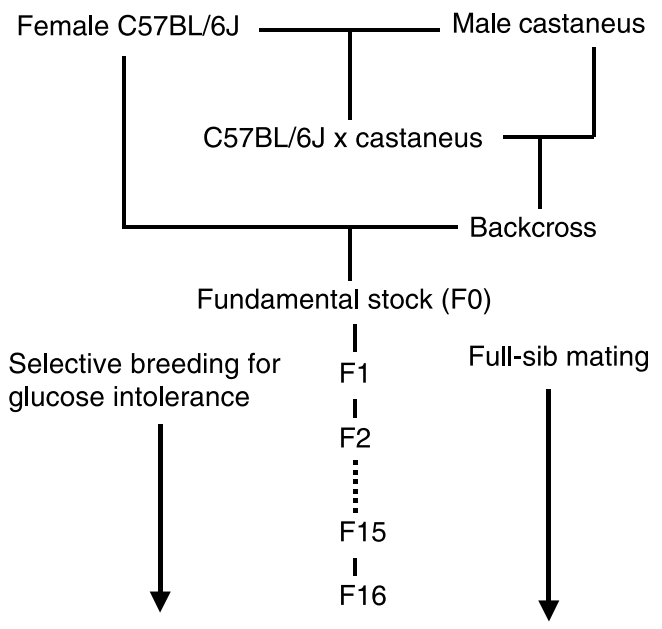

Figure 1 The pedigree of HND mice developed from the male Mus musculus castaneus mouse and the female B6 mice. 
or fasting mice at 6, 12, 20 and 40 weeks of age. Serum samples were collected and stored at $-30{ }^{\circ} \mathrm{C}$ until assayed. Serum immunoreactive insulin concentrations were measured by RIA (ShionoRIA; Shionogi, Osaka, Japan) with rat insulin as standard. The IPGTT was performed at $6,12,20,30$ and 40 weeks of age by the following protocol. After a 14-h fast (from 2000 to $1000 \mathrm{~h}$ ), blood samples were collected from the tail vein (fasting or 0 min sample in IPGTT). Then, a 20\% solution of glucose $(2 \mathrm{~g} / \mathrm{kg}$ body weight $)$ was injected intraperitoneally, followed by blood sampling at 30, 60 and $120 \mathrm{~min}$ after the injection. Blood glucose concentrations were measured by the glucose oxidase method with a Glucose-B Test Kit (Wako, Osaka, Japan). The area under the glucose curve (AUC) in the IPGTT was calculated by the trapezoid rule from the glucose measurements at 0 (fasting), 30, 60 and $120 \mathrm{~min}(\mathrm{mg} \times \mathrm{min} / \mathrm{dl})$. Mice were defined as diabetic when blood glucose concentrations exceeded $200 \mathrm{mg} / \mathrm{dl}$ at $120 \mathrm{~min}$ after glucose administration.

\section{In vivo insulin response to glucose}

After 14-h fast (from 2000 to $1000 \mathrm{~h}$ ) of male HND and B6 mice at 7 and 23 weeks of age, blood samples $(150 \mathrm{ml})$ were collected from tail vein without anesthesia. Then, a $20 \%$ solution of glucose $(2 \mathrm{~g} / \mathrm{kg}$ body weight $)$ was injected intraperitoneally, and blood samples $(150 \mathrm{ml})$ were collected 10 and $30 \mathrm{~min}$ after the injection. Insulin concentrations in the samples were measured by RIA.

\section{Insulin secretion from isolated pancreatic islets}

Insulin secretion from isolated islets was evaluated by batch incubation. Pancreatic islets were isolated from male HND and B6 mice at 20 weeks of age by collagenase digestion. Batches of four size-matched islets were preincubated for $60 \mathrm{~min}$ at $37^{\circ} \mathrm{C}$ in $0.6 \mathrm{ml}$ Hepes-buffered Krebs-Ringer solution $(119 \mathrm{mmol} / \mathrm{l} \mathrm{NaCl}$, $4.75 \mathrm{mmol} / \mathrm{l} \quad \mathrm{KCl}, \quad 5 \mathrm{mmol} / \mathrm{l} \quad \mathrm{NaHCO}_{3}, \quad 2.54 \mathrm{mmol} / \mathrm{l}$ $\mathrm{CaCl}_{2}, \quad 1.2 \mathrm{mmol} / \mathrm{l} \quad \mathrm{MgSO}_{4}, \quad 1.2 \mathrm{mmol} / \mathrm{l} \quad \mathrm{KH}_{2} \mathrm{PO}_{4}$, $20 \mathrm{mmol} / \mathrm{l}$ HEPES, (pH 7.4)) with $3 \mathrm{mmol} / \mathrm{l}$ glucose and $0.5 \%$ BSA. After preincubation, the medium was carefully replaced with BSA-containing, Hepes-buffered Krebs-Ringer solution with different glucose concentrations $(3-40 \mathrm{mmol} / \mathrm{l})$ and various substances. Islets were further incubated for $60 \mathrm{~min}$ at $37^{\circ} \mathrm{C}$, and insulin released into the incubation media was determined by RIA.

\section{In vivo blood glucose response to clonidine, an a2-adrenergic receptor agonist}

After 14-h fast (from 2000 to $1000 \mathrm{~h}$ ) of male HND and B6 mice at 14 weeks of age, blood samples were collected from tail veins. Then, clonidine $(50 \mu \mathrm{g} / \mathrm{kg}$ body weight, dissolved in saline) or saline (control) was injected intraperitoneally. Subsequently, blood samples were collected at 30,60 and 120 min after the injection for glucose determination.

\section{In vivo effect of yohimbine, an $\alpha 2$-adrenergic receptor antagonist, on insulin response to glucose}

After 14-h fast (from 2000 to $1000 \mathrm{~h}$ ) of male HND and B6 mice at 15 weeks of age, yohimbine $(100 \mu \mathrm{g} / \mathrm{kg}$ body weight, dissolved in saline) or saline was injected intraperitoneally. Blood samples $(150 \mu \mathrm{l})$ were collected 30 min after the injection from the tail vein without anesthesia. Then, a $20 \%$ glucose solution was injected intraperitoneally ( $2 \mathrm{~g}$ glucose $/ \mathrm{kg}$ body weight), and blood samples $(150 \mu \mathrm{l})$ were collected $30 \mathrm{~min}$ after the injection. Insulin concentrations in these samples were measured by RIA.

\section{Statistical analysis}

All results are expressed as mean \pm S.E.M. Statistical analysis was by Student's $t$-test. Differences with $P<0.05$ were regarded as significant.

\section{Results}

\section{Incidence of impaired glucose tolerance, and time-dependent changes in growth curve and body-mass index in HND mice}

Table 1 shows the incidence of impaired glucose tolerance estimated at $6,12,20,30$ and 40 weeks of age in 16-42 HND mice. The incidence was the highest $(80 \%)$ at 12 weeks of age, and subsequently declined to $25 \%$ at 40 weeks of age. As shown in Fig. 2A, the body weight of HND mice was about $54 \%$ of that of B6 mice at 6 weeks of age, and $46 \%$ at 40 weeks of age. The body weight of $\mathrm{B} 6$ mice kept increasing until 40 weeks of age, but in HND mice its growth reached a plateau $(22 \mathrm{~g})$ at 20 weeks of age. BMI at 6 weeks of age in HND mice was significantly lower than that in B6 mice (HND mice, 0.225 \pm 0.004 ; B6 mice, $0.259 \pm 0.003)$, and the difference remained until 40 weeks of age (Fig. 2B).

Table 1 Incidence of impaired glucose tolerance in male HND (F12) and C57BL/6J mice at 6, 12, 20, 30 and 40 weeks of age.

\begin{tabular}{lccccc}
\hline $\begin{array}{l}\text { Age } \\
\text { (weeks) }\end{array}$ & $\mathbf{6}$ & $\mathbf{1 2}$ & $\mathbf{2 0}$ & $\mathbf{3 0}$ & $\mathbf{4 0}$ \\
\hline HND & $74 \%$ & $80 \%$ & $63 \%$ & $43 \%$ & $25 \%$ \\
& $(31 / 42)$ & $(16 / 20)$ & $(15 / 24)$ & $(13 / 30)$ & $(4 / 16)$ \\
C57BL/6J & $0 \%$ & $0 \%$ & $0 \%$ & $0 \%$ & $0 \%$ \\
& $(0 / 12)$ & $(0 / 14)$ & $(0 / 14)$ & $(0 / 14)$ & $(0 / 14)$ \\
\hline
\end{tabular}

Numbers in parenthesis indicate number of mice with impaired glucose tolerance/number of mice tested. 


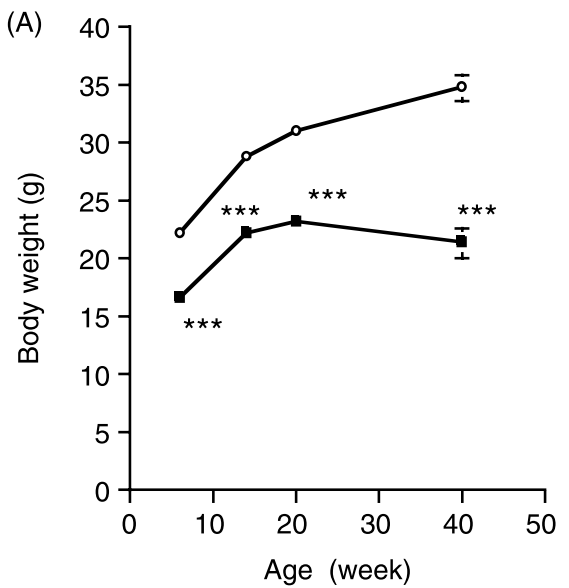

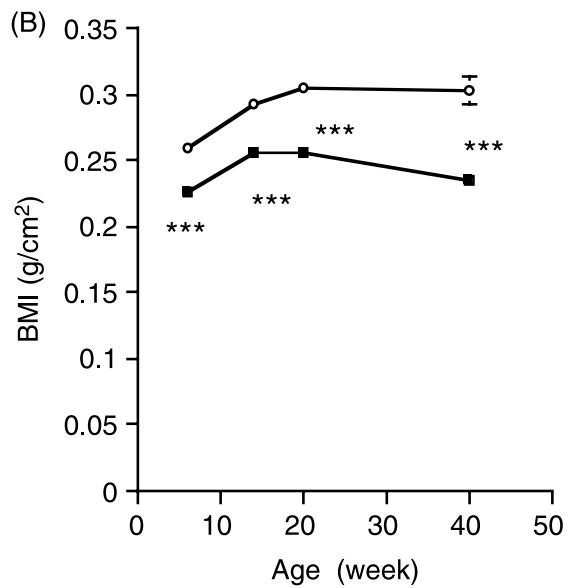

Figure 2 Age-dependent changes in body weight $(A)$ and $B M I(B)$ of HND $(\square, n=12)$ and $\mathrm{B} 6(\mathrm{O}, n=12)$ mice. Each symbol represents the mean \pm S.E.M. ${ }^{* \star \star} P<0.001$ vs $\mathrm{B} 6$

\section{Blood glucose levels}

Nonfasting blood glucose concentrations in HND mice at 6,12 and 20 weeks of age were significantly higher than those in B6 mice (Fig. 3A). The glucose concentrations in HND mice declined thereafter, and reached a level similar to those in B6 mice at 30 weeks of age. The fasting blood glucose levels in HND mice were significantly higher than those in B6 mice (Fig. 3B). The levels in HND mice also declined with age, and were comparable to those in B6 mice at 20 and 40 weeks of age.

\section{Intraperitoneal glucose tolerance test (IPGTT)}

Glucose tolerance in HND mice assessed by IPGTT was impaired at 6, 12, 20 and 30 weeks of age (Fig. 4A-D), but not at 40 weeks of age (Fig. 4E). In all points of age examined so far, the blood glucose concentrations at 30 min in IPGTT were similar in HND and B6 mice. The concentrations at 60 and $120 \mathrm{~min}$ in IPGTT in HND mice were significantly higher than those in B6 mice at $6,12,20$ and 30 weeks of age, but not at 40 weeks of age. Figure 5 shows the value of area under curve (AUC) in IPGTT. The values in HND mice was significantly higher than those in $\mathrm{B} 6$ mice at 6-30 weeks of age, but, again, not at 40 weeks.

\section{Serum insulin levels and insulin sensitivity}

We measured nonfasting and fasting serum insulin concentrations at 6, 23 and 40 weeks of age. At all points of age, significant differences between B6 and HND mice were not observed at either nonfasting or fasting levels (data not shown). Moreover, the insulin tolerance test was done at 7,20 and 40 weeks of age. At all points of age, decline of the blood glucose concentrations after insulin injection $(0.5 \mathrm{IU} / \mathrm{kg}$ body weight, intraperitoneally) was similar in HND and B6 mice.

\section{In vivo insulin response to glucose}

Changes in the serum insulin concentrations after intraperitoneal injection of glucose at 7 weeks of age are shown in Fig. 6. Serum concentrations of B6

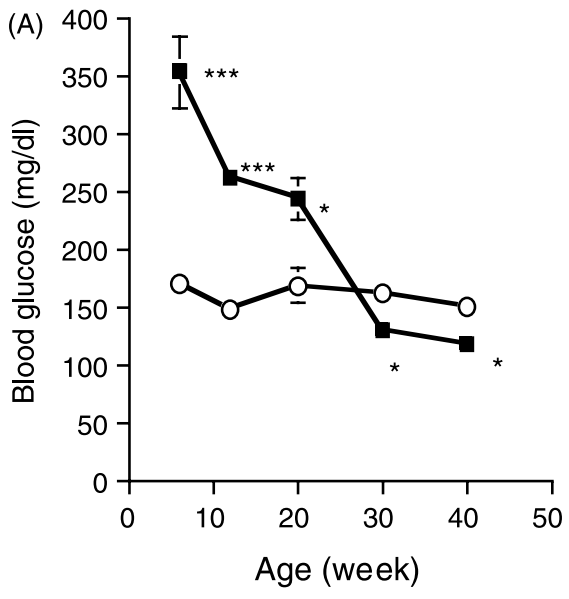

www.eje-online.org

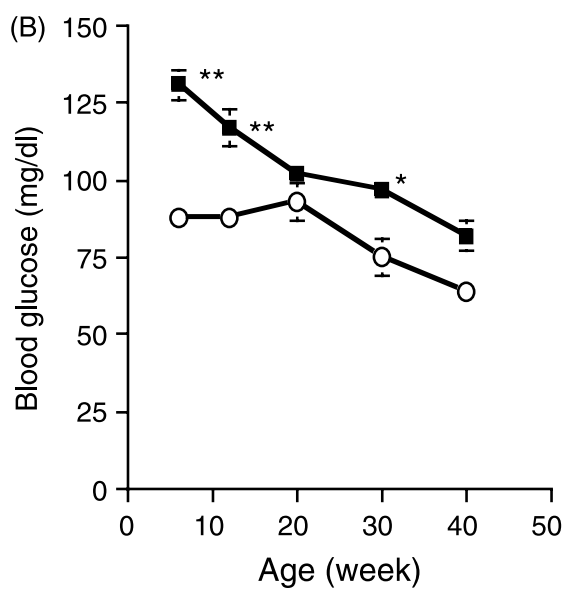

Figure 3 Age-dependent changes in nonfasting $(A)$ and fasting $(B)$ blood glucose concentrations in HND $(\mathbb{\square}, n=12)$ and $\mathrm{B} 6(\mathrm{O}, n=12)$ mice. Values are mean \pm S.E.M. ${ }^{*} P<0.05$ vs $\mathrm{B} 6$ mice; $* \star P<0.01$ vs $\mathrm{B} 6$ mice; ${ }_{\star * *} P<0.001$ vs $\mathrm{B} 6$ mice. 


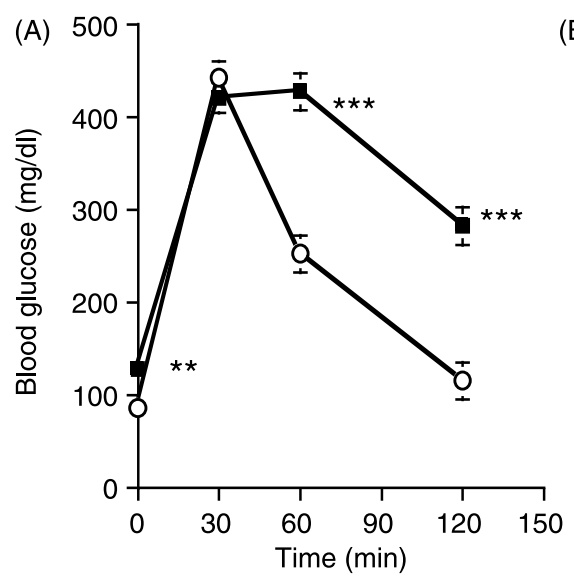

(B)
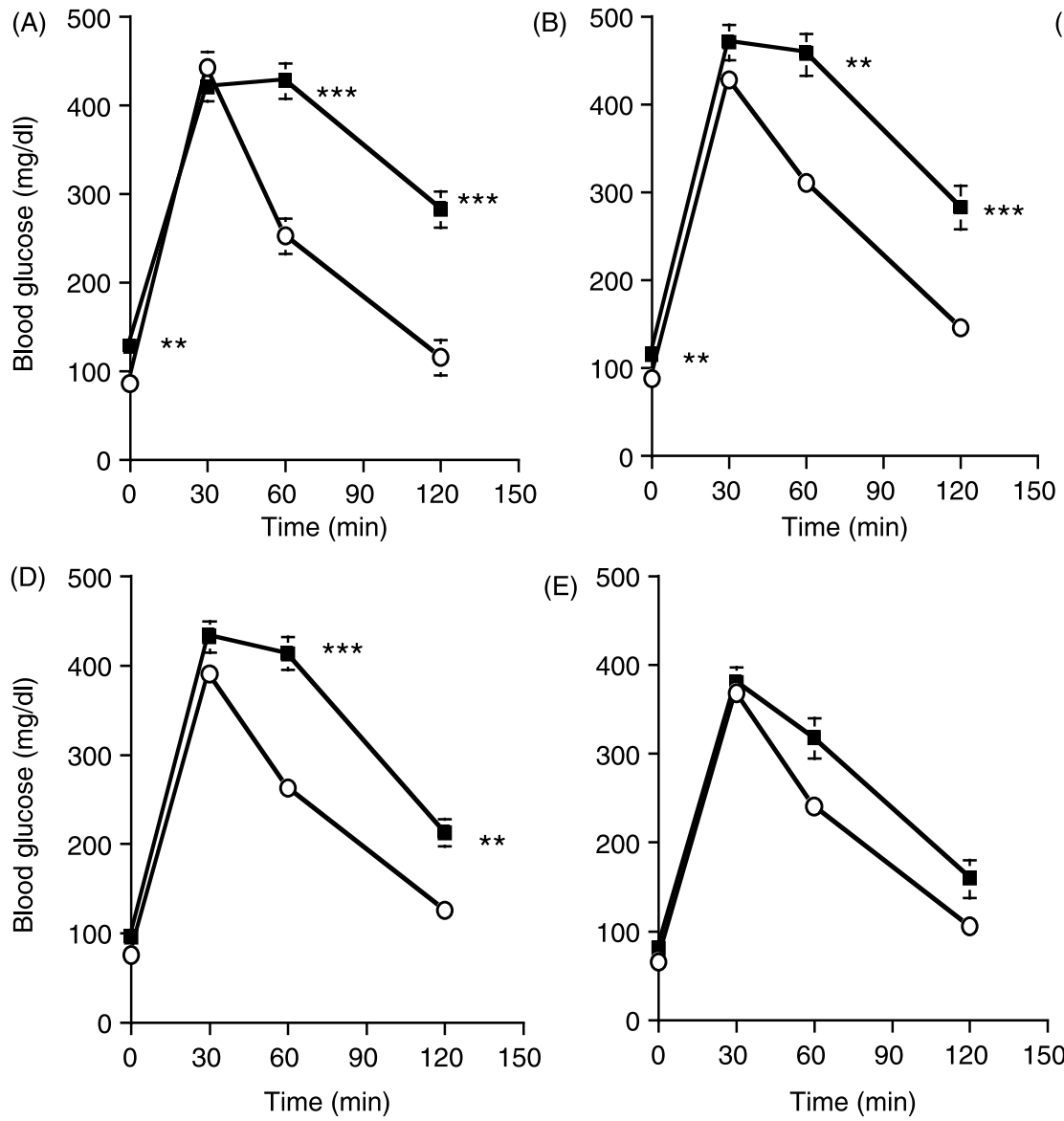

(E)

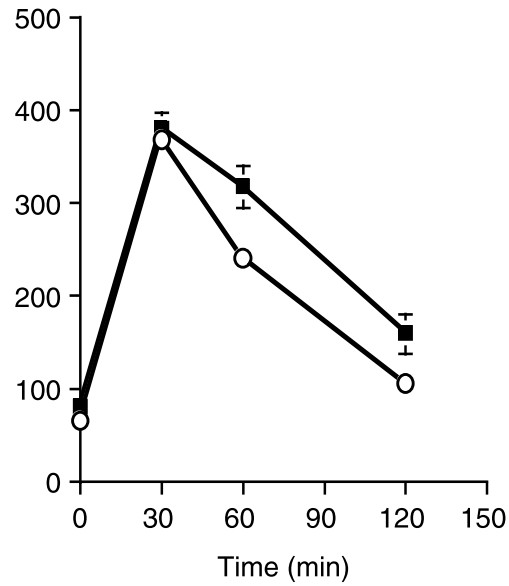

(C) 500

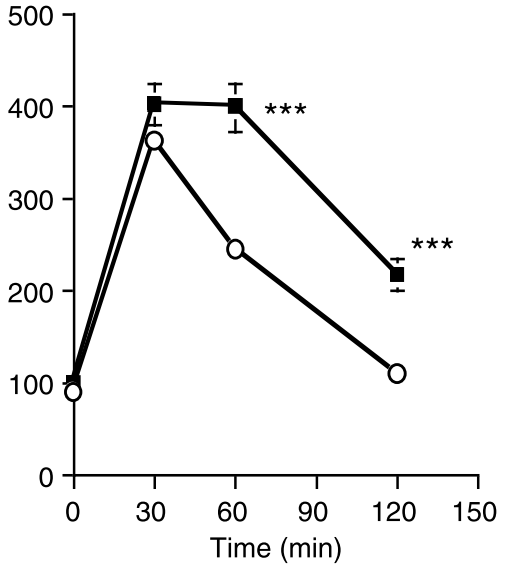

Figure 4 Glucose tolerance by IPGTT at 6 (A), 12 (B), 20 (C), 30 (D) and 40 (E) weeks of age in HND ( $\square, n=12)$ and B6 (O, $n=12)$ mice. Values are mean \pm S.E.M. ${ }^{\star \star} P<0.01$ vs B6 mice; ${ }^{\star \star \star} P<0.001$ vs $B 6$ mice.

mice at $10 \mathrm{~min}$ after the injection were increased by $130 \%$ when compared with the preinjection value, and at $30 \mathrm{~min}$ by $160 \%$. The serum insulin concentrations in HND mice at 10 and $30 \mathrm{~min}$ after the

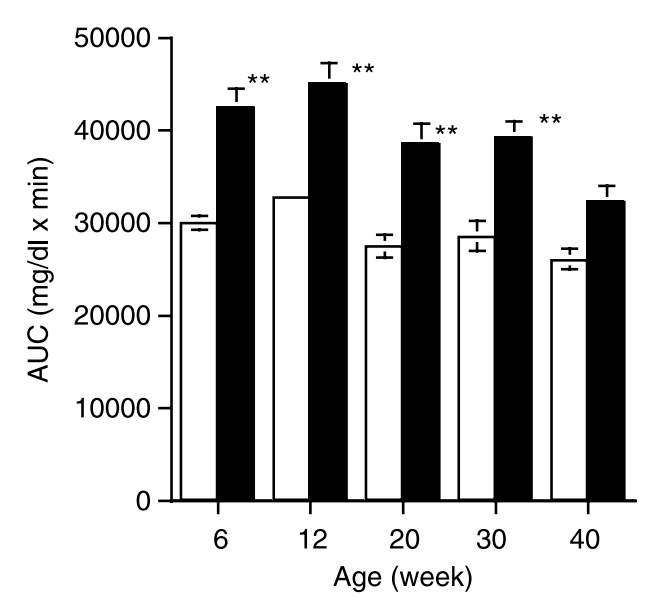

Figure 5 Longitudinal analysis of AUC in IPGTT in HND (black bars) and B6 (open bars) mice. Values are mean \pm S.E.M. ${ }^{\star \star} P<0.01$ vs $\mathrm{B} 6$ mice. injection were almost the same as the preinjection levels. At 23 weeks of age (data not shown), elevation of the serum insulin concentrations in response to glucose injection was scarcely observed in HND mice. 


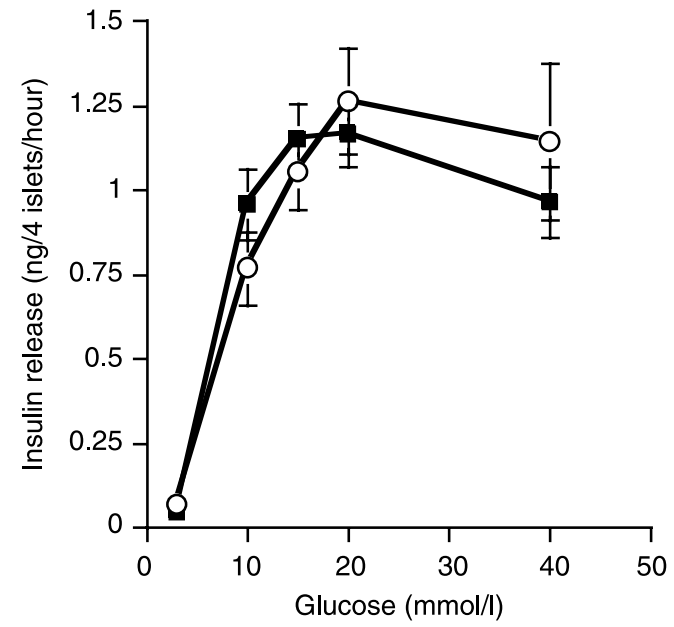

Figure 7 Dose-dependent changes in insulin secretion in response to glucose from HND $(\square)$ and $B 6(O)$ isolated islets. Number of samples at each concentration of glucose was four in both strains. Values are mean \pm S.E.M.

\section{Glucose-induced insulin release from isolated islets}

Glucose-induced insulin release from isolated islets was examined by batch incubation (Fig. 7). Insulin response from HND islets to $3,10,15,20$ and $40 \mathrm{mM}$ glucose was not different from that from B6 islets. Potentiation of insulin secretion by GLP-1 $(100 \mathrm{nmol} / \mathrm{l})$, GIP $(100 \mathrm{nmol} / \mathrm{l})$ or glucagon $(100 \mathrm{nmol} / \mathrm{l})$ in the copresence of $15 \mathrm{mM}$ glucose was also comparable between HND and B6 mice (data not shown). Inhibition of insulin release by epinephrine or the $\alpha 2$-adrenergic receptor agonist clonidine was examined in isolated islets of HND and B6 mice (Fig. 8A and B). In the presence of $1 \mathrm{nM}$ epinephrine, inhibition of glucoseinduced insulin secretion was more pronounced in HND islets than the control (Fig. 8A). Similarly, $10 \mathrm{nM}$ clonidine inhibited insulin secretion from HND islets more potently than B6 islets (Fig. 8B). We also examined the effects of somatostatin, another hormone/ neurotransmitter which also suppresses glucose-stimulated insulin release via inhibitory trimeric G protein (Gi), on insulin release from pancreatic islets, but no difference was found between HND and B6 islets (data not shown).

\section{In vivo blood glucose response to clonidine}

We examined the in vivo effect of clonidine, an $\alpha 2$ adrenergic receptor agonist, on the blood glucose concentration in fasted HND and B6 mice at 14 weeks of age. Fasting blood glucose concentration in HND and B6 mice was 111.3 \pm 15.2 and $73.4 \pm 7.6 \mathrm{mg} / \mathrm{dl}$ respectively. Elevation of the glucose level in HND mice, when expressed as a difference from the fasting values, was more obvious than that in $\mathrm{B} 6$ mice at 30,60 or $120 \mathrm{~min}$ after the injection (Fig. 9).

\section{In vivo effect of yohimbine, an $\alpha 2$-adrenergic receptor antagonist, on insulin response to glucose}

We examined the in vivo effect of yohimbine ( $\alpha 2$-adrenergic receptor antagonist) pretreatment on insulin response to glucose in HND and B6 mice at 15 weeks of age. In B6 mice pretreated with saline, the intraperitoneal injection of glucose increased serum insulin concentration by $160 \%$ compared with the preinjection value (Fig. 10A). Pretreatment with yohimbine did not affect the insulin response to glucose injection in B6 mice (Fig. 10A). In HND mice pretreated with saline, the elevation of serum insulin concentration after glucose injection was not observed (Fig. 10B). However, pretreatment with yohimbine revealed remarkable elevation of the serum insulin concentration (by $105 \%$ ) by glucose injection (Fig.10B).

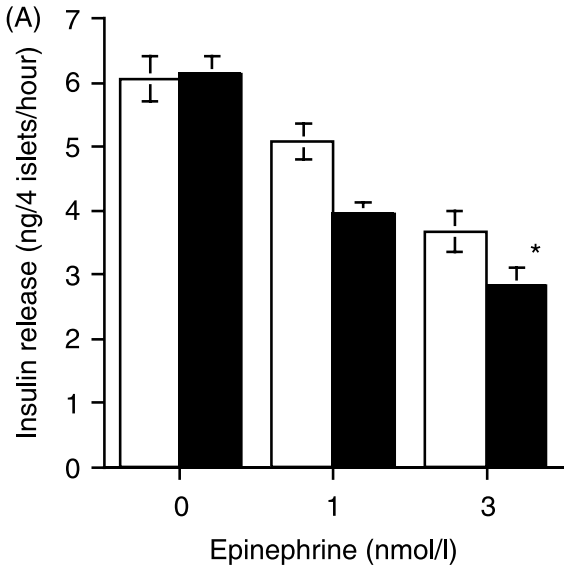

www.eje-online.org

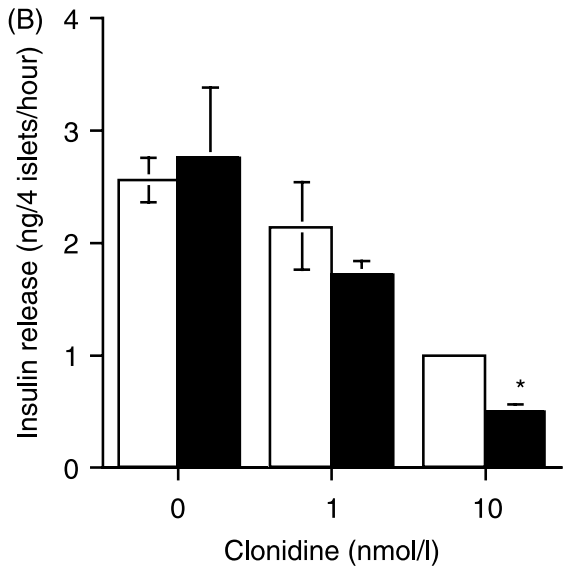

Figure 8 Effect of epinephrine (A) and clonidine (B) on glucose $(20 \mathrm{mmol} / \mathrm{l})$-induced insulin release from HND (black bars) and B6 (open bars) isolated islets. Number of samples at each concentration of glucose was four in both strains. Values are mean \pm S.E.M. ${ }^{*} P<0.05$ vs $\mathrm{B} 6$ mice. 


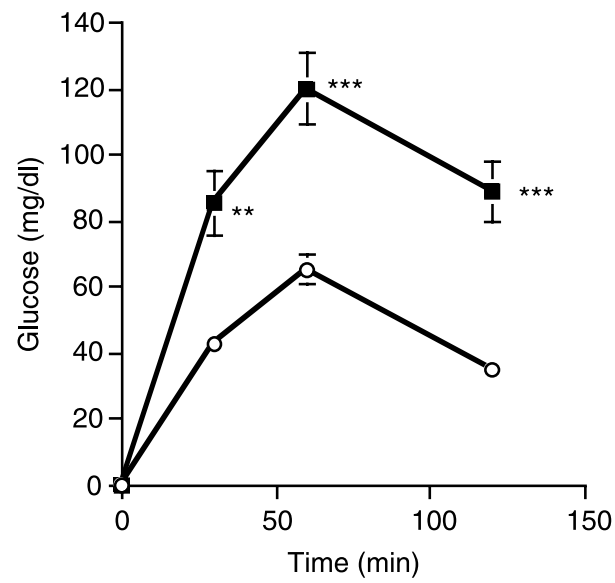

Figure 9 Time-dependent changes in blood glucose concentration after intraperitoneal injection of clonidine $(50 \mu \mathrm{g} / \mathrm{kg}$ body weight) in fasted HND $(\boldsymbol{\square}, n=5)$ and B6 $(\bigcirc, n=5)$ mice at 14 weeks of age. Values are mean \pm S.E.M. ${ }^{* \star} P<0.01$ vs $\mathrm{B} 6$ mice; ${ }_{\star * *} P<0.001$ vs $\mathrm{B} 6$ mice.

\section{Discussion}

The present study demonstrated that the HND mouse spontaneously developed hyperglycemia with a high incidence rate at an early age, and had a lean body and low BMI. This model may be interesting for investigating the etiology and pathogenesis of type 2 diabetes. We also found that that pancreatic $\beta$-cells in HND mice possess hypersensitivity via the $\alpha 2$-adrenergic receptor, resulting in the development of impaired glucose tolerance.

Insulin release from pancreatic $\beta$-cells is regulated by highly complex and sophisticated mechanisms. It is modulated by many factors, including hormones, neuropeptides and neurotransmitters (21). It is well known that endocrine pancreas is richly innervated by autonomic neurons, and that insulin secretion by $\beta$-cells is strongly inhibited by epinephrine/norepinephrine released from the sympathetic nerve terminals or adrenal glands. Previous studies (22-24) showed that the inhibitory effect of epinephrine on insulin secretion is mainly due to activation of the $\alpha 2$-adrenergic receptors located on the cell membrane of the $\beta$-cell. Binding studies with selective ligands revealed the response of $\alpha 2$-adrenergic receptors on islet cell membranes isolated from rats (25). Catecholamines decrease intracellular cyclic AMP and regulate ion channel activities via the $\alpha 2$-adrenergic receptor coupled with trimeric Gi protein (26).

The $\alpha 2$-adrenergic receptor family comprises three receptor subtypes, $\alpha 2 \mathrm{~A}, \alpha 2 \mathrm{~B}$ and $\alpha 2 \mathrm{C}$, encoded by distinct genes (27), and these three receptors in mice have been already cloned in mice (28-30). $\alpha 2 \mathrm{~A}$-adrenergic receptor mRNA has been detected in human and rat pancreatic islets $(31,32)$. Although the relevant receptor subtype is not directly examined in this study, there is evidence that the $\alpha 2 \mathrm{~A}$ subtype is involved in the impairment of insulin secretion $(33,34)$. Devedjian et al. (35) generated transgenic mice overexpressing human $\alpha 2 \mathrm{~A}$-adrenergic receptor selectively in the pancreatic $\beta$-cell. The transgenic mice showed modest glucose intolerance, and evident hypoinsulinemic hyperglycemia after injection of the $\alpha 2 \mathrm{~A}$-adrenergic agonist. The impaired glucose tolerance in the transgenic mice was abolished by pretreatment with the $\alpha 2$-adrenergic antagonist. These phenotypes in the transgenic mice are quite similar to those observed in HND mice in the present study. The impaired glucose tolerance in HND mice was also recovered by pretreatment with the $\alpha 2$-adrenergic receptor antagonist, yohimbine (data not shown).

We suppose that the reduced incidence of hyperglycemia in the older HND mouse may be due to an agedependent decrease in sympathetic activity. This change results from reduced catecholamine secretion from the sympathetic nerve terminals and/or decreased sensitivity of the relevant adrenergic receptors, as reported in the heart and artery $(36,37)$.

To examine genetic traits of diabetes in HND mice preliminarily, B6 female mice were mated with a HND (F14) male mouse to produce hybrid mice, and the

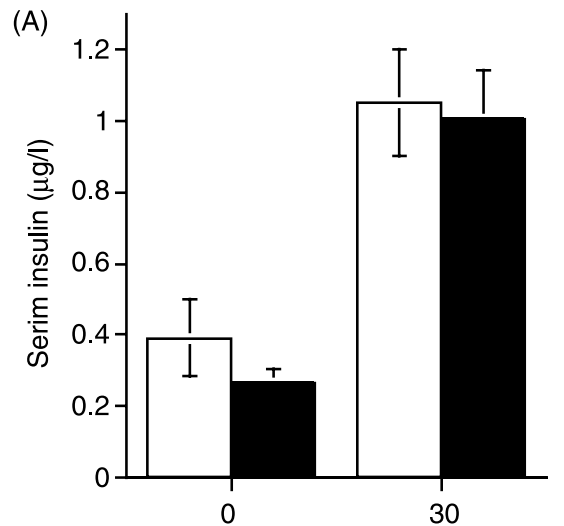

Time ( $\mathrm{min})$ after the glucose injection

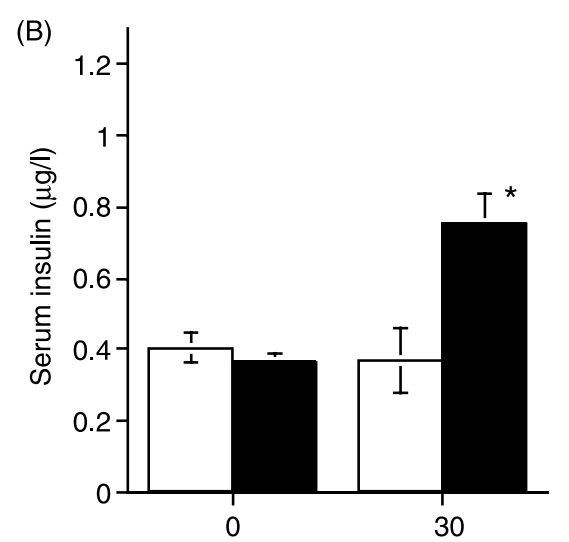

Time (min) after the glucose injection
Figure 10 Effect of pretreatment with yohimbine (intraperitoneal injection, $100 \mu \mathrm{g} / \mathrm{kg}$ body weight) (black bars, $n=4$ ) or saline (open bars, $n=4$ ) on in vivo insulin response to glucose in $\mathrm{B} 6$ (A) and HND (B) mice at 15 weeks of age. Values are mean \pm S.E.M. ${ }^{\star} P<0.05$ vs saline-treated group. 
hybrid mice were intercrossed to produce intercross mice. The incidence of impaired glucose tolerance in the intercross mice was less than 25\%, suggesting that the diabetic phenotype of HND mice is carried by more than one responsible gene. The parental castaneus mouse did not show glucosuria, although we did not check the blood glucose levels. We suppose that the diabetic traits in HND mice are composed of genes having epistatic effects from both castaneus and B6 mice. In the future, genetic analyses, such as chromosomal mapping, will clarify the diabetogenic genes that contribute to diabetic phenotypes of HND mice. One drawback of the HND mice is their low reproduction ability. In HND mice, average litter size after F13 generations was $3.2 \pm 0.4$.

In the pathogenesis of type 2 diabetes, the role of neural regulation of insulin secretion in glucose homeostasis remains unclarified. At present, the available animal models for investigating this role are very limited. Therefore, we expect the HND mouse to prove a useful model of type 2 diabetes with impaired insulin release. The present results suggest that the alleles from wild castaneus and B6 mice interact in the HND mouse genome, leading to hypersensitivity of pancreatic $\beta$-cells to epinephrine and impaired glucose tolerance. We expect that novel causative genes of common type 2 diabetes will be identified with the diabetic HND mouse.

\section{Acknowledgements}

This work was supported by a Grant-in Aid for Scientific Research (B) (no. 11556024) from the Japan Society for the Promotion of Science and by a grant from the Elizabeth Arnold Fuji Foundation, Japan.

\section{References}

1 Waram JH, Rich SS \& Krolewski AS. Epidemiology and genetics of diabetes mellitus. In Joslin's Diabetes Mellitus, pp 201-215. Eds RC Kahn \& G Weir. Philadelphia: Lea and Febiger, 1994.

2 Karasik A \& Hattori M. Use of animal models in the study of diabetes. In Joslin's Diabetes Mellitus, pp 317-350. Eds RC Kahn \& G Weir. Philadelphia: Lea and Febiger, 1994.

3 Froguel P, Vaxillaire M \& Velho G. Genetic and metabolic heterogeneity of maturity-onset diabetes of the young. Diabetes Review $19975123-130$.

4 Fioderek FT. Rodent genetic models for obesity and non-insulindependent diabetes mellitus. In Diabetes Mellitus, pp 604-618. Eds D LeRoith, S Taylor \& J Olefsky. Philadelphia: LippincottRaven, 1996.

5 Zhang Y, Proenca R, Maffei M, Barone M, Leopold L \& Friedman J. Positional cloning of the mouse obese gene and its human homologue. Nature 1994372 425-432.

6 Chen H, Charlat O, Tartaglia L, Woolf E, Weng X, Ellis S, Lakey N, Culpepper J, Moore K, Breitbart R, Dyuk G, Tepper R \& Morgenstern J. Evidence that the diabetes gene encodes the leptin receptor: identification of a mutation in the leptin receptor gene in $d b / d b$ mice. Cell 199684 491-495.

7 Phillips M, Liu Q, Hammond A, Dugan V, Hey P, Caskey C \& Hess J. Leptin receptor missense mutation in the fatty Zucker rat. Nature Genetics $19961318-19$.
8 Naggert JK, Fricker LD, Valamov O, Nishina P, Rouille Y, Steiner D, Carroll R, Paigen B \& Leiter E. Hyperinsulinemia in obese fat/fat mice associated with a carboxy peptidase E mutation which reduces enzyme activity. Nature Genetics 199510 135-142.

9 Kawano K, Hirashima T, Mori S \& Natori T. OLETF (Otsuka LongEvans Tokushima Fatty) rat: a new NIDDM rat strain. Diabetes Research and Clinical Practice 199424 S317-S320.

10 Nishimura M. Breeding of mice strains for diabetes mellitus. Experimental Animals 196918 147-157.

11 Ueda H, Ikegami H, Yamato E, Fu J, Fukuda M, Shen G, Kawaguchi Y, Takekawa K, Fujioka Y, Fujisawa T, Nakagawa Y, Hamada Y, Shibata M \& Ogihara T. The NSY mouse: a new animal model of spontaneous NIDDM with moderate obesity. Diabetologia 199538 503-508.

12 Suzuki W, Iizuka S, Tabuchi M, Funo S, Yanagisawa T, Kimura M, Sato T, Endo T \& Kawamura H. A new mouse model of apontaneous diabetes derived from ddY strain. Experimental Animals 199948 181-189.

13 Goto Y, Kakizaki M \& Masaki N. Spontaneous diabetes produced by selective breeding of normal Wistar rats. Proceedings of the Japan Academy $1975 \mathbf{5 1} 80-85$.

14 Taya C, Kaneda H, Sakaizumi M, Miyashita N, Moriwaki K \& Yonekawa H. Preservation of wild mouse genes by embryo and gamete freezing. In Genetics in Wild Mice, Its Application to Biomedical Research, pp 313-324. Eds K Moriwaki, T Shiroishi \& H Yonekawa. Tokyo: Japan Scientific Societies and SAG Kalger, 1994.

15 Clegg J. Travels with DNA in the Pacific. Lancet 1994344 1070-1072.

16 Coleman DL. Diabetes and obesity: thrifty mutants? Nutrition Reviews 19785 129-132.

17 Surwit RS, Kuhn CM, Cochrane C, McCubbin JA \& Feingloss MN. Diet-induced type II diabetes in C57BL/6J mice. Diabetes 198837 1163-1167.

18 Surwit RS, Seldin MF, Kuhn CM, Cochrane C \& Feingloss MN. Control of expression of insulin resistance and hyperglycemia by different genetic factors in diabetic C57BL/6J mice. Diabetes $19914082-87$.

19 Copeland NG, Jenkins NA, Gilbert DJ, Eppig JT, Maltis LJ, Miller JC, Dietrich WF, Weaver A, Lincoln SE, Steen RG, Stein LD, Nadeau JH \& Lander ES. A genetic linkage map of the mouse: current application and future prospects. Science 1993262 57-66.

20 Fioderek FT. Rodent genetic models for obesity and non-insulindependent diabetes mellitus. In Diabetes Mellitus, pp 604-618. Eds D LeRoith, S Taylor \& J Olefsky. Philadelphia: LippincottRaven, 1996.

21 Smith PH \& Porte D Jr. Neuropharmacology of the pancreas islets. Annual Review of Pharmacology and Toxicology 197616 269-285.

22 Nakadate T, Nakaki T, Muraki T \& Kato R. Adrenergic regulation of blood glucose levels: possible involvement of postsynaptic alpha-2 type adrenergic receptors regulating insulin release. Journal of Pharmacology and Experimental Therapeutics 1980215 226-230.

23 DiTullio NW, Cieslinski L, Matthews WD \& Storer B. Mechanisms involved in the hyperglycaemic response induced by clonidine and other alpha2 adrenoceptor agonists. Journal of Pharmacology and Experimenal Therapeutics 1984228 168-173.

24 Angel I, Bidet S \& Langer S. Pharmacological characterization of the hyperglycemia induced by alpha-2 adrenoceptor agonists. Journal of Pharmacology and Experimental Therapeutics 1988246 1098-1103.

25 Persaud SJ, Jones PM \& Howell SL. Effects of Bordetella pertussis toxin on catecholamine inhibition of insulin release from intact and electrically permealized rat islets. Biochemical Journal 1989 $258669-675$.

26 Bylund DB. Subtypes of alpha 2-adrenoceptors: pharmacological and molecular biological evidence converge. Trends in Pharmacological Sciences $19889356-361$. 
27 Bylund DB, Eikenberg DC \& Hieble JP. International Union of Pharmacology nomenclature of adrenoceptors. Pharmacological Review 199446 121-136.

28 The FANTOM Consortium and the RIKEN Genome Exploration Research Group Phase I \& II Team, Analysis of the mouse transcriptome based on functional annotation of 60,770 full-length cDNAs. Nature $2002 \mathbf{4 2 0} 563-573$.

29 Chruscinski AJ, Link RE, Daunt DA, Barsh GS \& Kobilka BK. Cloning and expression of the mouse homolog of the human alpha 2-C2 adrenergic receptor. Biochemistry and Biophysics Research Communications $1992 \mathbf{1 8 6} 1280-1287$.

30 Link R, Daunt D, Barsh G, Chruscinski A \& Kobilka B. Cloning of two mouse genes encoding alpha 2-adrenergic receptor subtypes and identification of a single amino acid in the mouse alpha 2-C10 homolog responsible for an interspecies variation in antagonist binding. Molecular Pharmacology 199242 $16-27$.

31 Lacey RJ, Chan SL \& Cable HC. Expression of alpha2- and betaadrenoceptor subtypes in human islets of Langerhans. Journal of Endocrinology $1996 \mathbf{1 4 8} 531-543$.

32 Chan SL, Perrett CW \& Morgan NG. Differential expression of alpha2-adrenoceptor subtypes in purified rat pancreatic islet Aand B-cells. Cell Signals $1997971-78$.
33 Angel I, Niddam R \& Langer SZ. Involvement of alpha-2 adrenergic receptor subtypes in hyperglycemia. Journal of Pharmacology and Experimental Therapeutics $1990 \mathbf{2 5 4} 877-882$.

34 Niddam R, Angel I, Bidet S \& Langer SZ. Pharmacological characterization of alpha-2 adrenergic receptor subtype involved in the release of insulin from isolated rat pancreatic islets. Journal of Pharmacology and Experimental Therapeutics 1990254 883-887.

35 Devedjian JC, Pujol A, Cayla C, George M, Casellas A, Paris H \& Bosch F. Transgenic mice overexpressing $\alpha 2 \mathrm{~A}$-adrenoceptors in pancreatic beta cells show altered regulation of glucose homeostasis. Diabetologia $2000 \mathbf{4 3} 899-906$.

36 Buchholz J, Sexton P \& Hewitt W. Impact of age on modulation of norepinephrine release from sympathetic nerves in the rat superior mesentery artery. Life Sciences $199862679-686$.

37 Dinenno FA, Dietz NM \& Joyner MJ. Aging and forearm postjunctional $\alpha$-adrenergic vasoconstriction in healthy men. Circulation $20021061349-1354$

Received 15 April 2005

Accepted 1 September 2005 